\title{
In Pursuit of Corporate Entrepreneurship: How Employees Perceive the Role of Formalization and Centralization
}

\author{
A.Emre Demirci \\ Department of Business Administration \\ Faculty of Economics and Administrative Sciences \\ Anadolu University \\ Tel: 90-222-335-0580/3341 E-mail: aedemirci@anadolu.edu.tr
}

Received: April 28, 2012

doi:10.5296/jmr.v5i3.3597
Accepted: May 26, 2013 Published: July 1, 2013

URL: http://dx.doi.org/10.5296/jmr.v5i3.3597

\begin{abstract}
Corporate entrepreneurship is one of the key strategies of today's organizations in search of acquiring and sustaining competitive advantage in the global markets. Although many companies claim that entrepreneurial spirit is an inherent part of their organizational cultures, it is not common to see organizations gained competitive edge through solid corporate entrepreneurship strategies. Among many other organizational antecedents and oxymorons that have impact on the entrepreneurial profiles of the organizations, formalization and centralization stand out among other variables as key characteristics of the organizational structures.

This study aims to analyze the relationship between corporate entrepreneurship, formalization and centralization. The findings of this study indicate that centralization and formalization have impact on the entrepreneurial behaviors within the companies. A sample of 273 surveys was collected from three leading companies operating in the ceramics industry.
\end{abstract}

Keywords: Management, Corporate Entrepreneurship, Centralization, Formalization, Intrapreneurship 


\section{Introduction}

The field of entrepreneurship has a recognized scientific community that expresses itself through large numbers of conferences and scientific journals (Bruyat \& Julien, 2001) as a result of its significant effects on both economic and corporate performance. Entrepreneurship is now considered as one of the most powerful tools to survive economic recessions and bottlenecks through creating new businesses and new jobs, fostering creative thinking and nurturing the economy itself. Entrepreneurship is even more crucial for developing countries since its vital role in economic growth, wealth creation and distribution, grows as we speak. While entrepreneurship and independent start-ups keep catching attention from academia, governments, NGOs and corporate world, another facet of entrepreneurship has also been under intense discussions for the last three decades.

Schumpeter (1934) is one of the earliest economists who brought the concepts of entrepreneurship and innovation together. In his studies, he defined entrepreneur as a person who combines existing factors in a unique and novel way to deliver value. His definition was obviously including new products, new services, new processes and new markets. Schumpeter (1934) also suggests that entrepreneurship and innovation are the main pillars of economic development and growth. Based on the same idea that suggests economies need innovation and entrepreneurship for prosperity, many researchers discussed that organizations at micro level also need to create novel products/services and processes, and foster entrepreneurial attitudes. These discussions led to the emergence of the management philosophy called corporate entrepreneurship.

We can argue that corporate entrepreneurship, as a relatively new facet of entrepreneurship, has become a higher priority on managers' agendas. Although number of studies attempted to reveal the differences and similarities between entrepreneurship and corporate entrepreneurship, many studies suggest that corporate entrepreneurship is a distinctive and unique phenomenon (Morris et al., 1994). Corporate entrepreneurship has been widely recognized as an effective management philosophy to survive corporate inertia and lack of innovation. Although it was studied under different names like strategic renewal (Guth \& Ginsberg, 1990) and intrapreneurship (Pinchot, 1985; Zahra \& Covin, 1995), basics idea behind its philosophy have remained identical. Many researchers defined corporate entrepreneurship as a commitment to create an entrepreneurial environment within the organization to foster innovation, calculated risk taking and proactiveness (Sharma \& Chrisman, 1999; Kanter, 1983; Pinchot, 1985; Zahra, 1995). In other words, corporate entrepreneurship philosophy is embodied in the organization to enhance organizations' responsiveness to changing environmental conditions through developing unique products/services, processes and organizational structures, and constantly seizing and exploiting promising opportunities with the acceptance of the risks of possible failures.

By adopting corporate entrepreneurship strategies, businesses seek to achieve better orientation for the needs of the market and required flexibility to survive in complex markets and, to build and sustain their competitive edge. Given the reality that the average survival 
rate for larger scale businesses is approximately half of a human being, businesses thrive to learn how to survive (DeGeus, 1996).

In order to deal with dramatic changes and to stay ahead of competition, it is needless to say that businesses are required to harness the potential of their human resources. Considering the current reality that innovation skills and innovation performance play a major role in survival, entrepreneurial skills of the work force must be set free to spark innovative efforts within the enterprise. We can argue that corporate entrepreneurship, as a new facet of entrepreneurship theory and practice, is considered to be one of the most sound and solid strategies for corporate survival. Corporate entrepreneurship requires businesses to have people with entrepreneurial skills. Individuals who are willing to take initiatives and responsibilities, feeling responsible for the outcomes of their actions no matter if they are successes or failures, willing to take calculated risks associated with their initiatives, seeking new ways of improvement and demanding control over their jobs can be considered as individuals with high entrepreneurial potential.

\section{Organizational Climate for Corporate Entrepreneurship}

If an organization is willing to stay ahead of competition and is seeking to rejuvenate itself on a constant basis, it needs to create the relevant dynamics to support corporate entrepreneurship. We can argue that there are certain organizational attitudes that represent its entrepreneurial profile and actually, these attitudes are mostly valid for any type of entrepreneurship. Stopford and Baden-Fuller (1994) suggest that, fostering entrepreneurship and innovation within the organization requires proactiveness, higher inspiration for organizational renewal, team orientation, capability to resolve dilemmas and learning capability. Organizations capable of linking their individuals with these organizational attitudes through the adoption of corporate entrepreneurship strategies are most likely to be successful in leading their people to engage in entrepreneurial activities.

We suggest that dedication and leadership by the senior management is a crucial part of corporate entrepreneurship strategies as these strategies are organization-wide and required to be managed formally by visionary leaders. Thus, people within the organization are encouraged to seize and exploit entrepreneurial opportunities. Ireland et al. (2006) suggest that creating a work environment that supports employees to innovate on their jobs is a major pillar of corporate entrepreneurship strategies. Dess and Lumpkin (2005) also suggest that organizations pursuing corporate entrepreneurship strategies need to have entrepreneurial orientation. They also suggest that entrepreneurial orientation represents a mindset and perspective on entrepreneurship that are embodied in the organizational processes and culture. Although many studies imply a strong emphasis on the top management's role in the creation of an entrepreneurial organization, many others also emphasize the role of employees in the successful corporate entrepreneurship initiatives. Thus, we can argue that the nature of corporate entrepreneurship is somewhat paradoxical. Ginsberg and Hay (1994) argues that corporate entrepreneurship is a both a 'top-down' and a 'bottom-up' process. Their perspective suggests that if an organization is to be successful in their corporate entrepreneurship strategies, an organizational climate that encourages people to take 
entrepreneurial initiatives needs to be created by senior management. In addition to the role of senior management, middle management also plays a vital role in promoting entrepreneurship within the enterprise. Studies suggest that middle managers function as agents of change and as for the corporate entrepreneurship strategies; middle management's contribution to the deployment of innovation and entrepreneurship strategies is of paramount importance for any organization (Hornsby et al., 2002).

Although these perspectives imply that corporate entrepreneurship strategies are formal, many other studies also suggest that corporate entrepreneurship activities can also be informal (Burgelman and Sayles, 1986; Zahra, 1993; Sharma, 1999). These perspectives suggest that there are two valid approaches in the emergence of corporate entrepreneurship. We argue that these two different perspectives should co-exist and equally important within the organization to be successful in the entrepreneurial initiatives. As corporate entrepreneurship is considered as a strategy and management philosophy, it should be sponsored by the organization and led by the different layers of management. Many organizations put their best effort to provide their employees with the work environment that supports taking initiatives and engage in entrepreneurial activities. It is obvious that such efforts should be managed formally to ensure that the sound and solid steps are taken towards being an entrepreneurial organization. On the other hand, the other side of the coin should not be overlooked. Entrepreneurship processes within the organization can occur in an autonomous way where employees take initiative without the formal sponsorship of the organization. Sharma (1999) suggests that these informal efforts can occur due to individual creativity and/or pursuit of self-interest. These self-directed efforts may or may not become a part of the formal structure of the organization. In many cases, especially when there is lack of formal sponsorship from the management, such self-directed efforts receive no interest and perish before any solid steps are taken. On the other hand, existence of a formal sponsorship significantly has a major impact on the success or failure of "bottom-up" entrepreneurial initiatives. Thus, ‘top-bottom` and `bottom-up` approaches should be considered as nested rather than being alternatives to each other. One conclusion that can be drawn from these discussions, any approach to encourage entrepreneurial attitudes within the organization significantly requires commitment and support from various layers of management.

In addition to the above mentioned approaches to the emergence and nourishing of corporate entrepreneurship, we can argue that there are internal factors that facilitate or inhibit corporate entrepreneurship.

\section{Internal Environment Conditions for Corporate Entrepreneurship}

In addition to the many external conditions triggering corporate entrepreneurship and innovation, there are organizational factors that need to be addressed about corporate entrepreneurship. Previous studies revealed that different organizational factors play integral role in the emergence and nourishing of corporate entrepreneurship (Guth and Ginsberg, 1990; Kuratko et al., 1990; Hornsby et al., 1992, 2002).

Hornsby et al. (1992) suggest that there are five major factors that are closely related with corporate entrepreneurship. According to their study, management support for corporate 
entrepreneurship, rewards and reinforcement, work discretion, time availability and organizational boundaries are among the major factors that affect corporate entrepreneurship.

Top management support is considered to be crucial for corporate entrepreneurship and innovation. It refers to the willingness of top management to provide the necessary resources and authority for projects including entrepreneurial and innovative initiatives (Pinto and Mantel, 1990). Such support delivers promises that efforts toward working outside the traditional boundaries and experimenting is valued and supported by senior management. In a nutshell, top management plays a very integral role in creating an organizational atmosphere wherein employees are strongly encouraged to engage in entrepreneurial activities (Seshadri and Tripathy, 2006). Many studies suggest that existence of a strong top management support enhances the entrepreneurship and innovation within the business (Damanpour and Schneider, 2006; Chandler et al., 2000).

Rewards and reinforcements is the perception of individuals that their entrepreneurial and innovative initiatives are recognized by the management. Rewards are considered to be an effective tool to reduce risk taking aversion of the employees. Minimizing risk aversion is integral to entrepreneurial success as agency theory assumes that agents within the organization tend to be risk averse because they have to confront uncertain results of entrepreneurial activities. Considering the reality that many entrepreneurial activities fail, agents should be encouraged to take calculated risks (Jones and Butler, 1992). Along with other approaches, providing employees with rewards make the organizational structure less resistant to change that in return allows corporate entrepreneurial activities to flourish (Hornsby et al., 2002).

Work discretion is another organizational factor that is associated with corporate entrepreneurial performance. Work discretion refers to the existence of autonomy within the organization. Whether employees have the ability to make decisions regarding their work is directly related with their attitudes toward engaging in entrepreneurial activities. Dess et al. (2003) also found that there is a strong relationship between work discretion and the outcome of entrepreneurial actions. We can argue that work discretion is also closely linked with top management support and recognition as it involves senior executives' commitment to tolerate failure and provide their employees with decision-making latitude. Delegation of authority and responsibility is also an integral part of their commitment (Holt et al., 2007). Holt et al.'s (2007) study reveals that some specific activities like providing work discretion are important to the facilitation of corporate entrepreneurship.

Time availability is about giving enough time to employees in order to support their entrepreneurial actions. In a broader perspective, organizational resources are defined to include people, equipment, machinery, knowledge, competencies, money and people. Availability of these resources and senior management's commitment to effectively allocate these resources for innovative actions is important for entrepreneurial orientation. Employees should perceive that all critical resources including time are provided for innovative activities. They should be given sufficient time to work on their innovative ideas. On the other hand, from a paradoxical standpoint, lack of resources sometimes facilitates actions toward 
experimentation and risk-taking. This approach about the availability of resources is acceptable as long as it leads to innovative actions (Chen and Cangahuala, 2010).

Finally, flexibility of organizational boundaries has direct impact on the corporate entrepreneurial performance of the organization. Many studies reveal that flexible organizational boundaries facilitate innovation and entrepreneurial processes (Miller et al., 2007; Hornsby et al., 2009). Organizations as open systems gather external information and share it among the individuals and departments. In that sense, flexibility of organizational boundaries is important as it enhances the flow of information between the external environment and the organization itself. Networking across organizational boundaries to create value is a powerful strategy for engaging in entrepreneurial and innovative activities (Austin et al., 2006). While flexibility of organizational boundaries enhances information flow, it also facilitates individual efforts toward innovation within the organization. People with entrepreneurial skills and tendencies are exposed to preset organizational parameters. When these organizational parameters are strictly defined, entrepreneurs in the organization will not have sufficient freedom to transform their ideas into new products/services, processes, and business models.

\section{Role of Formalization and Centralization in Corporate Entrepreneurship}

Organizational factors are generally considered as the most influential factors that have potential to enhance or inhibit entrepreneurial orientation. Among all relevant organizational factors that can potentially affect corporate entrepreneurial performance, formalization and centralization can be considered as two main factors that are closely linked with corporate entrepreneurship. Although the nature and impact of other organizational factors are more evident, the role of formalization and centralization is somewhat more ambiguous.

\section{Formalization and Corporate Entrepreneurship}

Formalization refers to the existence and use of explicit rules, procedures and policies (Zhang and Han, 2012). However, we can argue that the relationship between formalization and corporate entrepreneurship is obsolete. Many studies note that formalization could inhibit corporate entrepreneurship and innovation as it constrains autonomy through strictly framing organizational rules and policies. In their studies, Burns and Stalker (1961) suggested that organic organizational systems are more suitable for innovation than mechanistic systems that refer to the tightly controlled and rigid organizational structures. Along with other characteristics such as narrow span of control, rigid specialization and little autonomy, high formalization is considered to be a major characteristic of mechanistic structures. Supporting this perspective, Aiken and Hage (1966) suggest that expressive relations are less prominent in highly formalized organizations.

In addition to the complex nature of structural relations between formalization, innovation and corporate entrepreneurship, employees' perceptions of the formalization level within the organization have impact on their behaviors. Dougherty and Hardy (1996) suggest that perceived formalization within the organization can constrain looking beyond existing 
practices that leverage employees' creative potential and hinder collaborative work processes vital to become an entrepreneurial and innovative organization.

Similarly, Jensen and Luthans (2006) found that the employees' perceptions of the level of formalization and dominant leadership style within the organization are highly correlated with their job satisfaction, organizational commitment and happiness at the work place. They suggest that organic structures with little formalization enhance job satisfaction, organizational commitment and work happiness that in return potentially drive employees to engage in entrepreneurial activities.

However, more recent studies revealed that the effects of formalization on corporate entrepreneurship and innovation are multidimensional. For example, Damanpour (1991) suggests that initiation and implementation of innovations should be considered separately. Damanpour's studies note that diverse and organic organizational structures initiate more innovations. But, on the other hand, organizations with more formal and centralized structures implement more innovations. Supporting this perspective, Damanpour's research found non-significant relations between innovation and formalization. Merz and Sauber (1995) reveal that high level of formalization hinders the entrepreneurial orientation of an organization while a moderate level of formalization is well received to achieve desired outcomes for entrepreneurial initiatives. Other recent studies also revealed that effective control and evaluation mechanism should be in place in order to support corporate entrepreneurial orientation (Kuratko et al., 1993; Antoncic and Hisrich, 2004). Supporting this perspective Ireland and Webb (2007) found that semi-formalization and semi-standardization contribute to the organizations' efforts to find efficient ways to use scarce resources during their exploration efforts. They also suggest that standardization and formalization some of the decision rules facilitate organizations to guide the exploration opportunities while creating knowledge search routines for using relevant resources in a more efficient way.

Supporting this perspective, Kirkhaug (2008) also found that some degree of formalization has impact on the implementation of organizational values by the employees. Based on the discussions by Kirkhaug, organizations with entrepreneurial values can utilize formalization to encourage their people to adopt these values and engage in entrepreneurial activities.

Considering the previous studies, we can argue that although the role of other organizational factors in corporate entrepreneurship and innovation is relatively more evident, the effects of formalization on entrepreneurial orientation are clearly debatable. Our study aims to shed more light on the controversial perspectives about the relations between formalization and corporate entrepreneurship.

\section{Centralization and Corporate Entrepreneurship}

Centralization is another organizational factor which is closely linked with corporate entrepreneurial orientation. We consider centralization as a function of work discretion - an important internal environmental factor that affects corporate entrepreneurship. We can also argue that centralization tends to be visible where highly formal practices exist within the 
organization. In general, centralization is the degree of decision making concentration. In other words, centralization refers to the extent to which decision making authority is in the possession of certain individuals, groups and positions (Grover, 1993; Ayers et al., 1997). Ireland and Webb (2007) define centralization of authority as the amount of autonomy individuals have to make decisions regarding the use of organizational resources.

Ghoshal and Bartlett's (1988) study of innovation and creativity at multinational companies revealed that local autonomy among other factors is closely associated with the "creation" process. Caruana et al. (1998) suggest that excessive centralization of decision making authority could potentially constrain entrepreneurial behavior within the organization that in return limits the individual performance. Rickards (1985) also suggest that creative solutions to problems within the organizations are mostly hindered by the centralization of authority. Barringer and Bluedorn (1999) found that high level of employee involvement facilitates firm-level entrepreneurial behavior and if entrepreneurship is to flourish within the organization, employees need to be free to identify and pursue opportunities. Similarly, Ireland and Webb (2007) suggest that potential effectiveness of an organization's exploration behaviors is affected and even enhanced through decentralization of authority. Thus, an organization become capable of analyzing relatively larger number of attractive market related opportunities.

As similar to the discussions about the relationship between formalization and corporate entrepreneurship, collaborative work which is clearly very important for innovation is also correlated with the decision making concentration within the organization. Jung et al. (2008) suggest that employees' perceptions about decision making autonomy have impact on collaborative work and innovation processes. They note that perceived centralization in the organizational structure can impede collaborative efforts needed for innovation and entrepreneurial orientation.

However, association between centralization and corporate entrepreneurship is not always linear. The nature and conditions in which the organizations operate can potentially change how centralization affects corporate entrepreneurship and innovation initiatives. Ghoshal and Bartlett's study (1988) claim that although higher level of autonomy facilitates the creativity and innovation processes, it is negatively correlated with the adoption of innovations created outside the organization. Birkinshaw's (1997) research findings were representing a duality about the relationship between centralization and market initiatives as a form of corporate entrepreneurship. About the local market initiatives, during the formative stage, it is better to have high autonomy whereas lower autonomy is more appropriate and desirable in advanced stages due to the managerial sponsorship.

\section{Research Design and Methodology}

\section{Research Hypotheses}

This research primarily aims to measure how employees perceive the role of formalization and centralization on corporate entrepreneurship. As mentioned in the literature review, many relevant studies have revealed that there are many internal and external factors that enhance 
or inhibit corporate entrepreneurial performance of the organizations. Among these many factors, this study focuses on two of the most debated internal factors that affect corporate entrepreneurship.

In order to explain the employees' perceptions on corporate entrepreneurial profile, formalization and centralization were considered due to the fact that how these two factors affect corporate entrepreneurship remains obsolete.

Hypotheses mentioned below were tested in order to determine whether formalization and centralization are antecedents or oxymorons for corporate entrepreneurial performance from the employees' perspectives.

H1. Formalization enhances entrepreneurial behavior within the organization.

H2. Centralization of authority hinders entrepreneurial behavior within the organization.

\section{Research Sample}

As this research aims to reveal the employees' perspectives on the effects of formalization and centralization on corporate entrepreneurship, subjects were drawn among the employees working at operational level in three leading companies operating in ceramics industry.

Considering the fact that majority of the relevant studies cover practices in western cultures, this study is expected to contribute to the corporate entrepreneurship literature due to the fact it reflects a perspective from eastern business practices.

The reason why ceramics industry was chosen for the study is that the industry itself requires extensive creative, innovative and entrepreneurial skills especially at the operational level. Unlike many other industries, there is much more room for employees to play around with the design, manufacturing and product development processes in the ceramics industry. There are still some manual processes that require significant level of employee contribution especially in the tasks related with design and product development.

Total number of 273 usable surveys was collected from three leading ceramics companies operating in Eskisehir region. These three companies can also be considered as major players in the ceramics industry at national level. 7 surveys filled out by managers were excluded from the analysis to have a homogenous sample. Homogeneity is also supported by choosing research subjects from the equivalent departments operating in three organizations.

Finally, three companies were chosen for the research as these companies are identical in terms of the number of employees, sales and specific field of operations. Although there are many other smaller companies operating in the ceramics industry, they were not considered for this research due to compatibility issues.

\section{Research Instrument}

Formalization, centralization and corporate entrepreneurship were measured by the scale as adopted by Caruana et al. (1998). Original formalization and entrepreneurship instruments were developed by Ferrell and Skinner (1988) while the corporate entrepreneurship scale was 
originally developed by Miller and Friesen (1983). This study replicates Caruana et al.'s (1988) study to test if the scale produces different results in companies operating in eastern business settings.

Centralization was measured with 5 questions, formalization was measured with 6 questions and finally, entrepreneurship was measured with 13 questions. All instruments in the scale consisted of five-point Likert-type scale items described by $1=$ Definitely Agree to $5=$ Definitely Disagree.

Scale reliability was tested in further studies by many other scholars (Ferrell and Skinner, 1988; Miller and Friesen, 1983; Covin and Slevin, 1989; Morris and Paul, 1987; Morris et al., 1993; Caruana et al., 1998) and their studies have revealed that the instrument is valid, reliable and internally consistent. In order to increase the reliability of the scale, each item was controlled and finally, three items that negatively affect the reliability were excluded from the analysis. Final analysis was completed with 21 items. We also found that the scale was reliable, valid and internally consistent. Our Cronbach Alpha value for the sample was 0.789 .

Scale was originally designed in English. As the study aims to measure the perceptions of Turkish employees, translated version of the survey was distributed to the research subjects. In order to increase the reliability of the translation, a translator native in English and fluent in Turkish has back-translated the scale into English to confirm the reliability of the initial translation. A colleague experienced in the field reviewed the back-translation with the researcher.

\section{Results and Discussions}

Descriptive statistics and correlations among the variables used in the study are presented in Table 1.1. The table shows that variables used for this study are consistent. On the other hand, results reveal that although there is a strong correlation between corporate entrepreneurship and formalization, there is no statistically significant correlation between corporate entrepreneurship and centralization.

Table 1. Correlations among the research variables

\begin{tabular}{llllll}
\hline Variables* & Mean & Std. Deviation & ENT & FORM & CENT \\
\hline ENT & 2.4973 & 0.6328 & 1,000 & & \\
FORM & 2.3891 & 0.6422 &, $551^{* *}$ & 1,000 & \\
CENT & 3.2095 & 0.5672 &, 040 &, 008 & 1,000 \\
\hline
\end{tabular}

**. Correlation is significant at the 0.01 level (2-tailed).

\section{ENT: EntrepreneurshipＦORM: Formalization}

CENT: Centralization

Table 1.2 shows the results of the multiple linear regression results for corporate entrepreneurship, formalization and centralization. 
Table 2. Perceived effects of formalization and centralization on corporate entrepreneurship

\begin{tabular}{llll}
\hline Indp. Variables* & Std. Beta & $\mathbf{t}$ & Sig. \\
\hline Formalization &, 551 & 0.6422 &, $000^{* *}$ \\
Centralization & 0,35 & 0.5672 &, 487 \\
\hline $\mathbf{R}^{2}=\mathbf{3 0 5}$ & $\mathbf{F}=\mathbf{5 9 , 2 9 8}$ & &
\end{tabular}

As seen in Table 1.2, about 30 percent of the corporate entrepreneurial profile within the considered organizations can be explained through independent variables. Other 70 percent can be explained through other internal and external variables that effect corporate entrepreneurship. Overall, it can be seen that there is a strong positive correlation between corporate entrepreneurship and formalization. On the other hand, according to our study employees do not perceive any solid relationship between corporate entrepreneurship and centralization. According to the results given above Hypothesis 1 is accepted and Hypothesis 2 is rejected.

Table 3. Hypotheses Test Results

\begin{tabular}{|c|c|}
\hline Hypotheses & Status \\
\hline $\begin{array}{l}\text { H1. Formalization enhances entrepreneurial behavior within the } \\
\text { organization. }\end{array}$ & Accepted \\
\hline $\begin{array}{l}\text { H2. Centralization of authority hinders entrepreneurial behavior within } \\
\text { the organization. }\end{array}$ & Rejected \\
\hline
\end{tabular}

\section{Formalization}

As seen in the tables we have found a strong correlation between formalization and corporate entrepreneurship. Our findings show that some degree of formalization enhances corporate entrepreneurial behavior within the organization. As discussed before relationship between formalization, corporate entrepreneurship and innovation remains obsolete. Efforts towards understanding the nature of this relationship are not surprising as formalization is an integral aspect of any organization. Bodewes (2002) argue that the conflicting perspectives about the relationship between formalization, innovation and corporate entrepreneurship stem from the different approaches to the definition of formalization. Different approaches to the definition of formalization reveal different perspectives on the nature this relationship. Aiken and Hage (1971) argue that organic structures would provide a suitable organizational context for creativity and innovation. Weick (1979) also claims that formalization creates a frame of reference that in return constrains exploration efforts within the exploration. According to Frederickson (1986), formalization breeds rigidity and conformity to organizational rules that in return impedes creativity and innovation as well as discouraging entrepreneurial behaviors. 
Similarly, Brown and Duguid (1991) suggest that less formalization is beneficial for uncovering the creative skills of the people within the organization.

On the other hand, many other research results reveal that some degree of formalization is needed to effectively manage creative and innovative processes within the organization. This perspective argues that formalization sets certain standards and common procedures for the members of the organization. Thus, some degree of formalization reduces the confusion, duplications and misinterpretation of tasks among employees. Supporting this perspective, Bonner et al. (2002) suggest that some degree of formal control is necessary for effective management. Duncan (1976) argues that high formalization can potentially foster corporate entrepreneurship and innovation through removing barriers that hinder the smooth execution and implementation of creative opinions. In their research, Jansen et al. (2006) found a positive relationship between the extent of rules and procedures within the organization and exploitative innovation. According to their findings, formalization makes existing knowledge and skills explicit and accelerates the diffusion of best practices between units.

In this sense, our findings also reveal that formalization enhances entrepreneurial behavior within the organization. Relatively higher formalization is a typical characteristic in organizations operating in high power distance cultures.

Michaels et al. (1988) found that there is no negative reaction to a formalized work environment. They also suggest that higher levels of formalization reduce the role ambiguity and role conflict within the organization. Similarly, Churchill et al. (1976) found that the employees tend to be more satisfied with their jobs when their supervisor provide them with immediate feedback and their performance is closely monitored. According to their research, employees are often are happier when their supervisors provide them with relatively high levels of structure, direction and support. This is because the employees feel more comfortable when they know what is expected from them and how their performance will be evaluated. Such a structure tends to reduce role ambiguity and role conflict. Organ and Green (1981) also found that the employees tend to suffer from lack of clarity in their roles and in the organizational context in which they carry out their jobs. They also claim that some degree of formalization reduces role ambiguity and enhance organizational identification.

Considering the results of these studies, we can argue that lack of formalization tend to blur what is expected from the employees that in return potentially causes employees to perceive that there is no guidance and support from the managers. Such an environment can also create uncertainty among the employees about their jobs.

Collectivist cultures are less likely to tolerate ambiguity and uncertainty. According to Hosftede's (1980) studies, Turkey scored high on uncertainty avoidance. Thus, we can argue that managers working with the members of a society that less likely to tolerate ambiguity usually reduce uncertainty through exercising authority, setting clear rules and regulations, and defining the clear work descriptions of their employees. Our findings support the perspective that Turkish respondents, as the members of an uncertainty avoiding culture, seek clarity in their job descriptions in order to effectively perform their duties and focus on entrepreneurial activities. Lack of structures, regulations, and clearly defined tasks and 
objectives tend to create role ambiguity and thus, employees in the studied organizations will most likely to capitalize their efforts to seek support and guidance instead of enhancing their entrepreneurial skills and focusing on creative and innovative ways of doing their tasks.

On the other hand, our study does not necessarily claim that the respondents seek rigid controls, strictly defined jobs, rules and regulations. But, some degree of formalization about what they are expected and how their performance will be evaluated should be clarified.

\section{Centralization}

Centralization is another organizational factor that has long been debated about its relations with corporate entrepreneurship, innovation and creativity. Although the results are not as controversial as in the case of formalization, there is still need for shedding some light on the topic. Unlike in the case of the relationship between formalization and corporate entrepreneurship, majority of the studies that focuses on centralization, corporate entrepreneurship and innovation reveals that higher level of centralization constrains individuals to access more ideas and information that in return hinders creativity and entrepreneurial behaviors within the organization. This point-of-view also claims that lower levels of centralization enhances creative thinking and foster employees to engage in entrepreneurial initiatives (Zaltman et al., 1973 ;)

Centralization is also a typical organizational characteristic for high power distance cultures. Thus, in many cases, relatively higher power distance cultures faces stronger barriers in implementing new strategies and fostering entrepreneurial behavior within the organization. This perspective led us to establish a hypothesis that predicts a negative correlation between corporate entrepreneurship and centralization. Contrary to our predictions, we could not find any statistically significant correlation between centralization and corporate entrepreneurship.

One reason that we could not find a correlation between corporate entrepreneurship and centralization in the studied organizations can be about their structures. All three organizations are currently managed by leaders with high entrepreneurial skills. Currently, all three companies are managed by the founding entrepreneurs. Although the decision making authority in these companies are centralized, their innovation performance is currently above the industry average. Our assumption is that if the employees participated in the research perceives their organizations already as entrepreneurial and innovative, centralization of authority is less likely to affect their perceptions on the entrepreneurial profile of their organizations.

\section{Limitations and Future Research}

Although this research contributes to the relevant literature by providing a case from eastern business practices, several limitations exist. First of all, the research subjects were drawn from organizations operating in one single industry. Results may vary in different industries as there are major differences from one industry to another. Future research should examine other industries in order to test the achieved results. 
Second limitation is that the subjects were drawn from employees at operational level. None of the respondents has a managerial position at any level. We assume that the perceptions about corporate entrepreneurship, formalization and centralization would radically change if the respondents were drawn among employees having managerial positions within the organization. Future research should investigate the other side of the coin and collect data from management staff to understand if there are major perceptional differences between managerial and non-managerial staff.

Third limitation is the conceptualization of the scale adopted for this research. As the adopted scale was originally developed in western cultural context, conceptualization of the scale by Turkish respondents should be re-tested in the future research. In addition to quantitative methods, qualitative data can be collected in order to fine-tune the scale for eastern cultures.

Fourth limitation is that the studied organizations are managed by the founding entrepreneurs along with other family member and non-family member managers. It is assumed that the high entrepreneurial skills of the founders are still affecting employees' perceptions on the entrepreneurial profile of their organizations. Future studies can study organizations led by professional managers instead of the entrepreneurs themselves. In such a case, future research may reveal correlations between corporate entrepreneurship and centralization as distinctive entrepreneurial skills of the founders may not be reflected in

Finally, there are other instruments that measure corporate entrepreneurship, formalization and centralization. Although the scale adopted for this study is reliable, valid and internally consistent, other available instruments can be considered in the future research. Another possibility is that several instruments can be combined to better measure the complex nature of the relationship between corporate entrepreneurship, formalization and centralization.

\section{References}

Aiken, M., \& Hage, J. (1971). The organic organization and innovation. Sociology, 5(1), 63-82. http://dx.doi.org/10.1177/003803857100500105

Aiken, M., \& Hage, J. (1966). Organizational alienation: A comparative analysis. American Sociological Review, 31(4), 497-507. http://www.jstor.org/stable/2090773

Antoncic, B., \& Hisrich, R.D. (2004). Corporate entrepreneurship contingencies and organizational wealth creation. Journal of Management Development, 23(6), 518-550. http://dx.doi.org/10.1108/02621710410541114

Austin, J., Stevenson, H., \& Wei-Skillern, J. (2006). Social and commercial entrepreneurship: Same, different, or both?. Entrepreneurship Theory and Practice, 30(1), 1-22. http://dx.doi.org/ 10.1111/j.1540-6520.2006.00107.x

Ayers, D., Dahlstrom, R., \& Skinner, Birkinshaw, J. (1997). Entrepreneurship in multinational corporations: The characteristics of subsidiary initiatives. Strategic Management Journal, 18(3), 207-229 
Barringer, B.R., \& Bluedorn, A.C. (1999). The relationship between corporate entrepreneurship and strategic management. Strategic Management Journal, 20, 421-444

Bodewes, W.E.J. (2002). Formalization and innovation revisited. European Journal of Innovation Management, 5(4), 214-223. http://dx.doi.org/10.1108/14601060210451171

Bonner, J. M., Ruekert, R. W., \& Walker, O. C. (2002). Upper management control of new product development projects and project performance. Journal of Product Innovation Management, 19(3), 233-245. http://dx.doi.org/10.1111/1540-5885.1930233

Brown, J. S., \& Duguid, P. (1991). Organizational learning and communities of practice: Toward a unified view of working, learning and innovation. Organization Science, 2(1), 134-148. http://dx.doi.org/10.1287/orsc.2.1.40

Burgelman, R.A., \& Sayles, L.R. (1986). Inside Corporate Innovation Strategy, Structure and Managerial Skills. New York: The Free Press

Burns, T., \& Stalker, G.M. (1961). The Management of Innovation. Travistock Publications

Bruyat, C., \& Julien, P.A. (2001). Defining the field of research in entrepreneurship. Journal of Business Venturing, 16(2), 165-180. http://dx.doi.org/10.1016/S0883-9026(99)00043-9

Caruana, A., Morris, M.H., \& Vella, A.J. (1998). The effect of centralization and formalization on entrepreneurship in export firms. Journal of Small Business Management, 36(1), 16-29

Chandler, G.N., Keller, C., \& Lyon, D.W. (2000). Unraveling the determinants and consequences of an innovation-supportive organizational culture. Entrepreneurship Theory and Practice, 25(1), 59-76

Chen, M.H., \& Cangahuala, G. (2010). Corporate entrepreneurship environment and organizational performance in technology manufacturing sector. Technology Management for Global Economic Growth (PICMET), 2010 Proceedings of PICMET '10, 1-9

Churchill, G.A., Jr., Ford, N.M., \& Walker, O.C., Jr. (1976). Organizational Climate and Job Satisfaction in the Sales force. Journal of Marketing Research, 13(4), 323-332. http://www.jstor.org/stable/3151014

Covin, J.G., \& Slevin, D.P. (1989). Strategic management of small firms in hostile and benign environments. Strategic Management Journal, 10(1), 75-87. http://dx.doi.org/10.1002/smj.4250100107

Damanpour, F. (1991). Organizational innovation: A meta-analysis of effects of determinants and moderators. The Academy of Management Journal, 34(3), 555-590. http://www.jstor.org/stable/256406

Damanpour, F., \& Schneider, M. (2006). Phases of the adoption of innovation in organizations: Effects of environment, organization and top managers. British Journal of Management, 17(3), 215-236. http://dx.doi.org/10.1111/j.1467-8551.2006.00498.x 
DeGeus, A. (1996). The Living Company. Boston, Harvard Business School Press

Dess, G.D., \& Lumpkin, G.T. (2005). The Role of entrepreneurial orientation in stimulating effective corporate entrepreneurship. The Academy of Management Executive (1993-2005), 19(1), 147-156. http://dx.doi.org/10.5465/AME.2005.15841975

Dess, G.G., Ireland, R.D., Zahra, S.A., Floyd, S.W., Janney, J.J., \& Lane, P.J. (2003). Emerging issues in corporate entrepreneurship. Journal of Management, 29(3), 351-378. http://dx.doi.org/10.1016/S0149-2063_03_00015-1

Dougherty, D., \& Hardy, C. (1996). Sustained product innovation in large, mature organizations: overcoming innovation-to-organization problems. Academy of Management Journal, 39(5), 1120-1153. http://www.jstor.org/stable/256994

Duncan, R.B. (1976). The ambidextrous organization: Designing dual structures for innovation. The Management of Organization Design, 1, 167-188

Ferrell, O.C., \& Skinner, S.J. (1998). Ethical behavior and bureaucratic structures in marketing research organizations. Journal of Marketing Research, 25(1), 103-109. http://www.jstor.org/stable/3172930

Fredrickson, J.W. (1986). The strategic decision process and the organizational structure. Academy of Management Review, 280-297. http://dx.doi.org/10.5465/AMR.1986.4283101

Ghoshal, S., \& Bartlett, C.A. (1988). Creation, adoption, and diffusion of innovations by subsidiaries of multinational corporations. Journal of International Business Studies, 19(3), 365-388. http://www.jstor.org/stable/155131

Ginsberg, A., \& Hay, M. (1994). Confronting the challenges of corporate entrepreneurship: Guidelines for venture managers. European Management Journal, 12(4), 382-389. http://dx.doi.org/10.1016/0263-2373(94)90024-8

Guth, W.D. \& Ginsberg, A. (1990). Corporate entrepreneurship. Strategic Management Journal, 11(5), 5-15

Hofstede, G.H. (1980). Cultures and Organisations: Software of the Mind, London, McGraw-Hill

Holt, D.T., Rutherford, M.W., \& Clohessy, G.R. (2007). Corporate entrepreneurship: An empirical look at individual characteristics, context, and process. Journal of Leadership \& Organizational Studies, 13(4), 40-54. http://dx.doi.org/10.1177/10717919070130040701

Hornsby, J.S., Kuratko, D.F., Shepherd, D.A., \& Bott, J.P. (2009). Managers' corporate entrepreneurial actions: Examining perception and position. Journal of Business Venturing, 24(3), 236-247. http://dx.doi.org/10.1016/j.jbusvent.2008.03.002

Hornsby, J.S., Kuratko, D.F., \& Zahra, S.A. (2002). Middle managers' perception of the internal environment for corporate entrepreneurship: assessing a measurement scale. Journal of Business Venturing, 17(3), 253-273. http://dx.doi.org/10.1016/S0883-9026(00)00059-8 
Ireland, R.D., \& Webb, J.W. (2007). Strategic entrepreneurship: Creating competitive advantage through streams of innovation. Business Horizons, 50(1), 49-59. http://dx.doi.org/10.1016/j.bushor.2006.06.002

Ireland, R.D., Kuratko, D.F., \& Morris, M.H. (2006). A health audit for corporate entrepreneurship: innovation at all levels: Part II. The Journal of Business Strategy, 27(2), 21-30. http://dx.doi.org/10.1108/02756660610650019

Jansen, J.J.P., Van Den Bosch, A.J., \& Volberda, H.W. (2006). Exploratory innovation, exploitative innovation, and performance: Effects of organizational antecedents and environmental moderators. Management Science, 52(11), 1661-1674. http://dx.doi.org/10.1287/mnsc.1060.0576

Jensen, S.M., \& Luthans, F. (2006). Entrepreneurs as authentic leaders: Impact on employees' attitudes. Leadership \& Organizational Development Journal, 27(8), 646-666. http://dx.doi.org/10.1108/01437730610709273

Jones, G.R., \& Butler, J.E. (1992). Managing internal corporate entrepreneurship: An agency

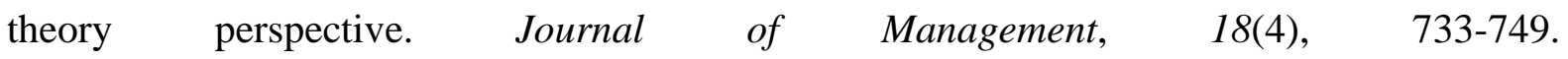
http://dx.doi.org/10.1177/014920639201800408

Jung, D.D., Wu, A. \& Chow, C.W. (2008). Towards understanding the direct and indirect effects of CEOs' transformational leadership on firm innovation. The Leadership Quarterly, 19(5), 582-594. http://dx.doi.org/10.1016/j.leaqua.2008.07.007

Kanter, R.M. (1983). The change masters. Simon and Schuster, New York

Kirkhaug, R. (2009). The management of meaning - Conditions for perception of values in a hierarchical organization. Journal of Business Ethics, 87(3), 317-324. http://dx.doi.org/10.1007/s10551-008-9920-z

Kuratko, D.F., Montagno, R.V., \& Hornsby, J.S. (1990). Developing an entrepreneurial assessment instrument for an effective corporate entrepreneurial environment. Strategic Management Journal, 11(5), 49-58. http://ssrn.com/abstract=1506387

Kuratko, D.F., Hornsby, J.S., Naffziger, D.W., \& Montagno, R.V. (1993). Implement entrepreneurial thinking in established organizations. SAM Advanced Management Journal, 58(1), 28-39

Merz, G.R., \& Sauber, M.H. (1995). Profiles of managerial activities in small firms. Strategic Management Journal, 16(7), 535-549. http://dx.doi.org/10.1002/smj.4250160705

Michaels, R.E., Cron, W.L., Dubinsky, A.J., \& Joachimsthaler, E.A. (1988). Influence of formalization on the organizational commitment and work alienation of salespeople and industrial buyers. Journal of Marketing Research, 25(4), 376-383. http://www.jstor.org/stable/3172948 
Miller, D.J., Fern, M.J., \& Cardinal, L.B. (2007). The use of knowledge for technological innovation within diversified firms. Academy of Management Journal, 50(2), 307-326. http://dx.doi.org/10.5465/AMJ.2007.24634437

Miller, D., \& Friesen, P.H. (1982). Innovation in conservative and entrepreneurial firms: Two models of strategic momentum. Strategic Management Journal, 3(1), 1-25. http://dx.doi.org/10.1002/smj.4250030102

Morris, M.H., Davis, D.L., \& Allen, J.W. (1994). Fostering corporate entrepreneurship: Cross-cultural comparisons of the importance of individualism versus collectivism. Journal of International Business Studies, 25(1), 65-89. http://www.jstor.org/stable/154852

Morris, M.H., Avila, R.A., \& Allen, J. (1993). Individualism and modern corporation: Implications for innovation and entrepreneurship. Journal of Management, 19(3), 595-612. http://dx.doi.org/10.1016/0149-2063(93)90006-9

Morris, M.H., \& Paul, G.W. (1987). The relationship between entrepreneurship and marketing in established firms. Journal of Business Venturing, 2(5), 247-259. http://dx.doi.org/10.1016/0883-9026(87)90012-7

Organ, D.W., \& Greene, C.N. (1981). The effects of formalization on professional involvement: A compensatory process approach. Administrative Science Quarterly, 26(2), 237-252. http://www.jstor.org/stable/2392471

Pinchot, G. III. (1985). Intrapreneuring. Harper and Row, New York

Pinto, J.K., \& Mantel, S.J., Jr. (1990). The causes of project failure. Engineering Management, IEEE Transactions, 37(4), 269-276. http://dx.doi.org/10.1109/17.62322

Rickards, T. (1985). Stimulating innovation: A systems approach, London, Pinter

Schumpeter, J.A. (1934). The theory of economic development. Cambridge: Harvard University Press

Seshadri, D.V.R., \& Tripathy, A. (2006). Innovation through intrapreneurship: The road less travelled. Vikalpa, 31(1), 17-29

Sharma, P., \& Chrisman, J.J. (1999). Toward a reconciliation of the definitional issues in the field of corporate entrepreneurship. Entrepreneurship Theory \& Practice, 23(3), 11-27. http://dx.doi.org/10.1007/978-3-540-48543-8_4

Stopford, J.M., \& Baden-Fuller, C.W.F. (1994). Creating Corporate Entrepreneurship. Strategic Management Journal, 15(7), 521-536. http://dx.doi.org/10.1002/smj.4250150703

Weick, K. E. (1979). The social psychology of organizing. AddisonWesley, Reading, MA.

Zaltman, G., Duncan, R., \& Holbek, J. (1973). Innovations and organizations. New York, John Wiley \& Sons

Zahra, S.A. (1993). A conceptual model of entrepreneurship as firm behavior: A critique and extension. Entrepreneurship Theory and Practice, 17(4), 5-21. 


\section{Macrothink}

Journal of Management Research ISSN 1941-899X 2013, Vol. 5, No. 3

Zahra, S.A., \& Covin, J.G. (1995). Contextual influences on the corporate entrepreneurship-performance relationship: a longitudinal analysis, Journal of Business Venturing, 10(1), 43-80. http://dx.doi.org/10.1016/0883-9026(94)00004-E

Zhang, H.Z., \& Han, Y. (2012). Team empowerment and the organizational context: Decentralization and the contrasting effects of formalization. Journal of Management, 38(2), 475-501. http://dx.doi.org/10.1177/0149206309342891 